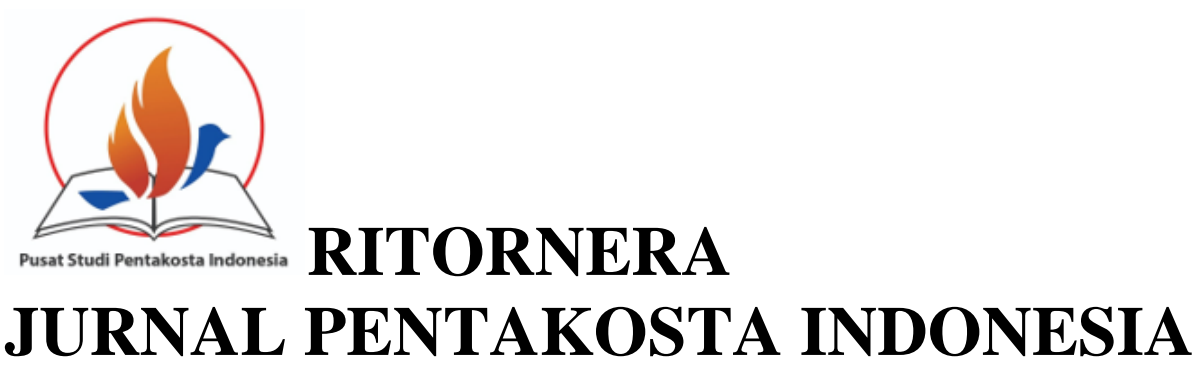

Vol. 1, No. 3, Desember 2021

Available at: pspindonesia.org

\title{
Telaah Kekinian Kotbah Topikal dari Perspektif Gereja Aliran Pentakosta
}

\author{
Rexi Tambunan ${ }^{1}$ \\ rexi03.tambunan@gmail.com \\ Sarah Andrianti2 \\ andriani.1234@gmail.com
}

\begin{abstract}
This study aims to explain the perspective of the Pentecostal church on topical preaching. Preaching is the delivery of God's message to the congregation through people who have been chosen by God. The research method used in this study is qualitative using a descriptive approach and literature review. Various types of preaching models are used by preachers. One of the most popular types of sermons is topical preaching. Because in the perspective of the Pentecostal church, it is known that there is no prohibition regarding the way someone delivers a sermon. The most important thing is to use the Bible as a basis for preaching. Based on the results of the discussion, the Pentecostal church interprets topical sermons as a way of delivering the content of the Bible that is relevant and contextual to the daily life of the congregation. Without reducing the essence and authority of God's word. Because God does not limit the way humans can preach or convey God's words. The preachers of the Pentecostal church believe that the Holy Spirit will guide the preacher to be able to prepare and deliver a sermon so that it is right on target.
\end{abstract}

Keywords: Topical Preaching; Church; Pentecost.

\begin{abstract}
Abstrak
Penelitian ini bertujuan untuk menjelaskan perspektif gereja aliran Pentakosta terhadap kotbah topikal. Kotbah merupakan penyampaian pesan Allah kepada jemaat melalui orangorang yang telah dipilih oleh Allah. Metode penelitian yang digunakan dalam penelitian ini adalah kualitatif dengan menggunakan pendekatan deskriptif dan kajian literatur. Berbagai jenis model kotbah dipakai oleh para pengkotbah. Salah satu jenis kotbah yang banyak disukai adalah kotbah topikal. Karena dalam perspektif gereja beraliran pentakosta diketahui tidak ada larangan terkait cara seseorang dalam menyampaikan kotbah. Yang terpenting adalah harus menggunakan Alkitab sebagai landasan dalam berkotbah. Berdasarkan hasil pembahasan, gereja aliran Pentakosta memaknai kotbah topikal sebagai salah satu cara penyampaian isi Alkitab yang relevan serta kontekstual dengan kehidupan jemaat sehari-hari.Tanpa mengurangi esensidan otoritas firman Allah.Karena Tuhan tidak membatasi cara manusia dalam berkotbah atau menyampaikan firman Tuhan.Para
\end{abstract}


pengkotbah gereja Pentakosta percaya bahwa Roh Kudus akan menuntun pengkotbah untuk dapat mempersiapkan dan menyampaikan kotbah sehingga tepat pada sasaran..

Kata kunci : kelahiran Yesus; natal; perayaan natal; misi ilahi; spritualitas pentakosta; teologi pentakosta

${ }^{1}$ STT Intheos Surakarta

\section{PENDAHULUAN}

Kotbah merupakan bentuk penyampaian pesan Allah secara komunikatif melalui orang yang dipilih-Nya dengan pertolongan Roh Kudus. Kotbah harus disertai penafsiran Alkitab yang sehat dan benar untuk memenuhi kebutuhan manusia akan firman Allah. Pengkotbah harus mempelajari kotbah dengan hati-hati mempersiapkan kotbah mereka sehingga dapat beresonansi secara baik dengan jemaat. ${ }^{1}$ Kotbah berasal dari kata homiletika berasal dari kata dasar bahasa Yunani "homilia" yang memiliki arti ceramah atau sebuah percakapan. Mengingat para pengkotbah di era gereja Kristen awal mengemas kotbah mereka kepada jemaat dalambentuk percakapan. ${ }^{2}$

Homeletika merupakan suatu keterampilan atau pengetahuan terkait berkotbah.Dimana dalam perkembangannya, terdapat berbagai macam bentuk kotbah. Salah satunya yang akan dibahas dalam penelitian ini yaitu tentang kotbah dengan jenis topikal. Karena jenis kotbah topikal saat ini semakin digemari oleh para pengkotbah - pengkotbah di mimbar gereja.Metode Topikal merupakansuatu bentuk kotbah di mana bagian utama diekstraksi dari sebuah topik tertentu atau pokok bahasan tertentu. Bagian utama dari kotbah ini diambil dari subjek itu sendiri dan tidak memerlukan teks referensi khusus. Kotbah dengan metode ini didedikasikan khusus kepada jemaat dengan membahas topik yang relevan dengan kehidupan jemaat. Agar setiap jemaat dapat dengan mudah menerima dan memahami isi kotbah secara utuh.

Menurut pandangan Jan S. Aritonang metode kotbah yang dipakai pengkotbah untuk mendapatkan kotbah yang memadai dan sesuai sasaran dapat disajikan melalui kotbah

\footnotetext{
${ }^{1}$ Yosua Sibarani, "Studi Evaluatif Model Khotbah Topikal Bagi Pengkhotbah Kristen," Jurnal Teologi (JUTEOLOG) (2020).

${ }^{2}$ William Evans, Cara Mempersiapkan Khotbah (Jakarta: BPK Gunung Mulia, 2011). 
topikal. ${ }^{3}$ Kotbah topikal dapat juga disebut sebagai kotbah sintetis dimana urutan ide utama atau topik yang dibahas tidak harus sesuai dengan urutan kemunculannya dalam ayat. Disebut juga teks karena gagasan utamanya berasal dari teks pendek Alkitab. Karena bagian utama kotbah didasarkan pada teks, maka teks perlu dikembangkan secara kreatif oleh pengkotbah tanpa mengurangi esensi dari firman yang disampaikan yaitu melalui analisis dan sintesis.Walaupun tidak bisa secara mutlak dan tidak dapat dikembangkan sesuka hati pengkotbah mengingat keterbatasan isi/materi, struktur dan format penyajian kotbah tersebut.

Aliran Pentakosta atau yang sering disebut Pentakostalisme merupakan istilah dalam kerangka teologi yang bersifat organisasi gerejawi atau denominatif. Gereja aliran Pentakosta sering kali terlibat dalam masalah dogmatis dan berbagai kontroversi teologis terkait ajaran Pentakosta itu sendiri. Berbagai pertanyaan seputar masalah pneumatologi telah menjadi perdebatan yang tidak pernah berakhir dalam persepsi umum dan sekaligus mewakili konstelasi baru dalam dunia teologi. Dimana beberapa kalangan menganggap Teologi yang dibangun oleh gereja pentakosta sebagai teologi yang tidak memiliki dasar Alkitab tetapi lebih sebagai teologi Alkitabiah terapan. ${ }^{4}$ Lebih lanjut Walter menyebutkan teologi yang dibangun oleh gereja pentakosta lebih kepada Teologi yang Dunamis atau Teologi yang digerakan oleh kuasa Roh Kudus. Meskipun demikian, tidak cukup kuat karena perlu pembuktian lebih lanjut guna menghadirkan pertanyaan-pertanyaan empiris sebagai landasan yuridisnya. ${ }^{5}$

Fenomena banyak terjadi di era modern ini adalah banyaknya kotbah - kotbah di mimbar gereja yang tidak dilandasi oleh unsur Alkitabiah. Sehingga hal ini menimbulkan keresahan bagi beberapa hamba Tuhan dan jemaat yang berpegang teguh pada ajaran Alkitab sebagai firman Allah yang tanpa salah dan penuh otoritas. Berdasarkan hal tersebut, dalam penelitian ini akan dibahas mengenai "Analisa Kotbah Topikal dalam Perspektif gereja aliran Pentakosta”. Apakah kotbah topikal relevan dengan gereja pentakosta dan bagaimana gereja aliran pentakosta memaknai kotbah topikal sebagai warna baru dalam kotbah di mimbar !

\footnotetext{
2016), 75 .

${ }^{3}$ Jan S. Aritonang, Berbagai Aliran Di Dalam Dan Di Sekitar Gereja (Jakarta: Gunung Mulia,

${ }^{4}$ Walter J. Hollenweger, Pentecostalism Origins and Developments World Wide (USA: Hendrickson Publisher, 1997), 24.

${ }^{5}$ Mark J. Cartledge, The Cambridge Companion to Pentacostalism (USA: Cambridge University Press, 2014), 254.
}

Copyright(C) 2021; Ritornera - Jurnal Teologi Pentakosta Indonesia, ISSN 2797-7676 (online), 2797$717 x$ (print) $\mid 27$ 


\section{METODE}

Penelitian ini menggunakanmetode penelitian kualitatif dengan pendekatan deskriptifserta melalui kajian literatur. ${ }^{6}$ Adapun pemilihan metode kualitatif dikarenakan karakteristik kualitatif yang memang memudahkan peneliti memberikan gambaran pemaknaan terhadap variabel yang diteliti yaitu kotbah topikal dan perspektif Pentakosta. Pendekatan deskriptif dipilih karena memberikan citra identitas Pentakostal melalui pola atau gaya hidup Kekristenan Awal sebagai pelopor dalam pembentukan Pentakostalisme klasik. Peneliti deskriptif menjelaskan pandangan Alkitab tentang para gereja di masa lalu dan kemudian menarik korelasinya saat ini. Tinjauan literatur membantu memperluas perspektif peneliti dan memberdayakan, meningkatkan, dan membenarkan penelitian mereka atas dasar ilmiah yang kuat. Kajian pustaka yang digunakan adalah Alkitab sebagai pedoman hidup Gereja Allah dan umat beriman, buku-buku yang layak menjadi topik pembahasan, dan artikel-artikel majalah yang relevan dan berharga baru dalam hal ini, selama lima tahun terakhir diterbitkan. Kesimpulan diambil dengan menggunakan deduksi dengan menggeneralisasikan konsep Alkitab sebagai parameter teologis gerakan Pantekosta gereja-gereja Pantekosta saat itu.

\section{HASIL DAN PEMBAHASAN}

\section{Peran Kotbah dalam Kekristenan}

Kotbah merupakan bagian dari liturgi ibadah di gereja yang bertujuan untuk memberikan penanaman dan pemahaman kepada jemaat terkait firman Tuhan. Namun demikian, tak jarang dijumpai di beberapa kotbah yang disampaikan, bukannya memberikan penjelasan yang Alkitabiah, justru sebaliknya yang hanya memberikan pernyataanpernyataan yang ambigu dan ambivalensi, bahkan cenderung provokatif. ${ }^{7}$ Conner $\&$ Malmin mengintisarikan bahwa Kotbah dianggap sebagai elemen terpenting dari ibadah gereja, karena Gereja memahami Firman Tuhan melalui kotbah. ${ }^{8}$ Kotbah yang baik harus disampaikan pada Pola Alkitab, berkotbah seperti yang dilakukan Tuhan Yesus Kristus dan para rasul dimana pemberitaan pesan Alkitab memiliki otoritas ilahi. Kotbah yang dilakukan

\footnotetext{
${ }^{6}$ Sonny Eli Zaluchu, "Strategi Penelitian Kualitatif Dan Kuantitatif Di Dalam Penelitian Agama," Evangelikal: Jurnal Teologi Injili dan Pembinaan Warga Jemaat 4, no. 1 (2020): 28.

${ }^{7}$ Kevin Tonny Rey, "Khotbah Pengajaran Versus Khotbah Kontemporer," DUNAMIS: Jurnal Penelitian Teologi dan Pendidikan Kristiani (2016).

${ }^{8}$ Jansakti Saddu Saly and Hasahatan Hutahaean, "PENGARUH KHOTBAH DALAM IBADAH MINGGU TERHADAP KEDEWASAAN IMAN JEMAAT DI GKSI MERAUKE,” VISIO DEI: JURNAL TEOLOGI KRISTEN (2020).
}

Copyright(C2021; Ritornera - Jurnal Teologi Pentakosta Indonesia, ISSN 2797-7676 (online), 2797$717 x$ (print) $\mid 28$ 
secara doktrinal bukan menjadi suatu kotbah yang banyak memberikan berbagai alasan konkrit, melainkan kotbah yang memiliki makna teologis dan aplikatif.

Kotbah pada dasarnya merupakan merupakan media pencerahan hati dan jiwa berdasarkan Firman Tuhan untuk membangun hubungan yang intim antara Tuhan Pencipta dan umat-umatNya, serta menjadi pedoman hidup yang menjadi dasar dalam membangun kadar rohani jemaat. Pengkotbah, di sisi lain, bukanlah iklan berjalan berdasarkan kepentingan individu atau kelompok, Kotbah bukan sekedar membuka Alkitab, membaca, dan berbicara dengan berapi-api, bergetar, tetapi menyampaikan kebenaran firman Allah dengan benar kepada jemaat pendengar. ${ }^{9} \mathrm{Hal}$ ini mengindikasikan bahwa eksistensi suatu kotbah yang disusun mestiharus terikat dan terbentuk dari kebenaran firman Tuhan. Yang terpenting adalah kebenaran bahwa suatu kotbah yang telah disusun dan disajikan bukan sekedar desain non empiris saja, melainkan paradigma interpretasi kontekstual untuk membangun harmoni kehidupan yang konstruktif, baik secara pribadi maupun sebagai kelompok pendengar, berdasarkan prinsip-prinsip Firman Tuhan.

Kotbah memainkan peran penting dalam ibadah Kristen karena kotbah adalah pewartaan firman Tuhan kepada umat Allah. ${ }^{10}$ Kotbah merupakan salah satu tradisi orang Yahudi yang kemudian berkembang dalam liturgi kekristenan. Secara teologis dapat dikatakan bahwapemberitan firmandi gerejaharus bertitik tumpuseutuhnya pada pemberitaanakan Tuhan Yesus, seperti yang dijelaskan dalam Korintus 2:4-5 "Sebab bukan diri kami yang kami beritakan, tetapi Yesus Kristus sebagai Tuhan..." Tuhan Yesus Kristus yang memuliakan Allah. Ayat ini menjelaskan bahwa pekerjaan berkotbah harus diakhiri dengan perspektif baru yaitu menyatakan kemuliaan Allah, yang diungkapkan melalui katakata. Pada hakekatnya, kotbah gereja harus menghasilkan tindakan nyata oleh anggota jemaatuntuk mengoreksi kehidupannya dan hidup dalam kasih karunia Tuhan Yesus Kristus.

Pandangan lain menghubungkan kotbah dengan seni menyajikan diskusi berdasarkan sumber-sumber otoritatif. Ini adalah seni berkotbah, karena kotbah itu sendiri disampaikan dalam kerangka interpretasi pribadi. ${ }^{11}$ Artinya, teks-teks alkitabiah yang diberitakan dalam konteks penafsiran tidak dapat dibuat secara mutlak atau sepenuhnya sewenang-wenang oleh siapa pun. Hal ini menunjukkan bahwa penafsiran yang satu bebas

\footnotetext{
${ }^{9}$ Sudarmin Purwocaroko, Homiletika Theologia Praksis Sajian Khotbah Alternatif (Yogyakarta: Narmada, 2010), 22.

${ }^{10}$ John Dami Mukese, Homiletika: Seni Berkhotbah Efektif (Yogyakarta: Nusa Indah, 2010), 19.

${ }^{11}$ Tiara Asrilita, "Studi Homiletika Pengaruh Pengkhotbah Tamu Dalam Pertumbuhan Iman Di JKI Immanuel Kudus,” SKRIPSI: Universitas Kristen Satya Wacana (2019). 
untuk menafsirkan kembali, tidak pernah berhenti menjadi mutlak, dan melengkapi yang lain.

Inti dari kotbah adalah menjadi sumber pendalaman isi firman Allah yang diberikan oleh Tuhan melalui perantaraan para gembala atau hamba Tuhan yang dipakai Tuhan untuk membimbing jemaat dalam rangka menumbuhkan iman jemaat Kristus. Kotbah sebagai pelayanan spiritual seperti yang disampaikan Hasan sutanto bahwa kotbah adalah bersifat spiritual yaitu membangun dari dalam ke luar. ${ }^{12}$ Untuk itu kotbah memainkan peran yang sangat penting dalam kehidupan gereja. Iman jemaat ditegaskan dengan pernyataan Firman Tuhan dalam semua peribadatan, baik dalam kebaktian minggu, persekutuan keluarga, dan kebaktian lainnya. Fungsi utamanya adalah penguatan iman jemaat yang merupakan penerimaan akan kebenaran perkataan Allah dan keterangan tentang sesuatu, meskipun tidak ada orang lain yang melihatnya sendiri. ${ }^{13}$ Setiap kotbah yang diterima oleh jemaat dari ibadah minggu dan persekutuan lainnya dapat membimbing kehidupan sehari-hari terutama dalam menjalin hubungan yang baik dengan keluarga, rekan kerja, kerabat, dan orang lain.

Pemberitaan Firman secara tidak langsung juga mengajak partisipasi jemaat untuk ikut serta dalam menyebarkan Injil. Kotbah merupakan bentuk dialog secara tidak langsung antara seorang pembawa firman dengan jemaat untuk mempelajari dan menemukan makna dari setiap isi Firman Tuhan. Karena Firman Tuhan memiliki fungsi yang sangat penting dalam kehidupan semua jemaat. Melalui kotbah jemaat diajak untuk lebih mengenal siapa Tuhan itu dan juga untuk meningkatkan iman serta pengharapannya kepada Tuhan. Iman jemaat akan terus bertumbuh dan tidak akan berhenti bertumbuh jika jemaat benar-benar memahami serta menghidupi Firman Tuhan.

Kotbah juga memegang peranan penting dalam membantu membawa perubahan hidup yang signifikan bagi jemaat yang mendengarnya. Seperti yang disampaikanAndreas B. Subagyo, bahwa Pelayanan Firman adalah pelayanan yang penting dalam suatu tatanan ibadah sehingga para rasul ingin memusatkan pikiran dalam doa dan pelayanan firman. ${ }^{14}$ Rasul Paulus memerintahkan agar 'Beritakanlah firman, siap sedialah baik atau tidak baik waktunya" (II Timotius 4:2).Karena Kotbah dapat dijadikan sebagai salah satu pedoman

23.

${ }^{12}$ Hasan Sutanto, Homiletik, Prinsip Dan Metode Berkhotbah (Jakarta: BPK Gunung Mulia, 2014),

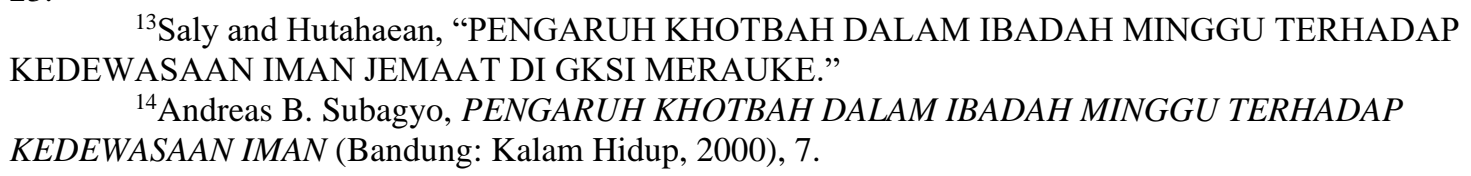

${ }^{13}$ Saly and Hutahaean, "PENGARUH KHOTBAH DALAM IBADAH MINGGU TERHADAP KEDEWASAAN IMAN JEMAAT DI GKSI MERAUKE."

${ }^{14}$ Andreas B. Subagyo, PENGARUH KHOTBAH DALAM IBADAH MINGGU TERHADAP KEDEWASAAN IMAN (Bandung: Kalam Hidup, 2000), 7.

Copyright(C2021; Ritornera - Jurnal Teologi Pentakosta Indonesia, ISSN 2797-7676 (online), 2797$717 \mathrm{x}$ (print) $\mid 30$ 
untuk berpikir oleh jemaat dari mulai hal yang kecil maupun perkara besar yang dikerjakan serta menghasilkan dampak baik serta menggiring jemaat kepada perubahan hidup semakin sempurna seperti Kristus.Oleh sebab itu, Kotbah merupakan wujud pemenuhan kebutuhan rohani yang diberikan oleh gereja untuk kehidupan jemaatyang dilayaninya.

Kotbah diyakini membawa pengaruh besar pada kedewasaan iman jemaat. Dalam studinya, Santoso menunjukkan bahwa kehadiran kotbah yang baik oleh seorang pendeta gereja secara signifikan meningkatkan pertumbuhan rohani jemaat. ${ }^{15}$ Anderson juga membenarkan hal ini. Dia mengatakan bahwa kotbah sebenarnya adalah salah satu indikator yang mempengaruhi kedewasaan suatu jemaat dan gereja . penyampaian firman di gereja merupakan sarana untuk memperlengkapi orang percaya menghidupi kebenaran di dalam Tuhan. ${ }^{16}$ Kedewasaan iman terjadi jika jemaat hidup di dalam Kristus yang adalah firman Tuhan. Seorang percaya menjadi dewasa oleh iman berarti seorang Kristen yang sempurna seperti Kristus. Bisa juga diartikan sebagai orang yang benar-benar mengenal Kristus melalui ciptaan, kasih, dan pengorbanan Kristus. ${ }^{17}$

\section{Model-model kotbah masa kini}

Kevin melihat dalam konteks kekinian sebetulnya kotbah bisa dikelompokan dalam dua model besar yaitu model kotbah pengajaran dan model kotbah yang sifatnya kontempores, yaitu dikategorikan berdasarkan model atau cara pembawannya, realitas yang ada menunjukkan bahwa terdapat 2 model atau cara membawakan suatu kotbah. ${ }^{18}$ Model kotbah pertama adalah kotbah pengajaran. Pengajaran kotbah berkaitan dengan kemampuan pengkotbah untuk menguasai pengetahuan teologi sistematika, teologi biblika, teologi sejarah, teologi praktis, dan hermeneutika. Kotbah kotbah bersifat deskriptif dan memberikan kesimpulan akhir yang dapat diterapkan sehingga gereja dapat berupaya menafsirkan kotbah yang diterima oleh jemaat. ${ }^{19}$ Isi kotbah tidak hanya menjadi kumpulan cerita - cerita dengan menggunakan bahasa pengantar yang cenderung kabur atau abstrak dengan istilah-istilah yang jauh dari kejelasan dan akhirnya tidak ditemukannya akhir pesan dari firman.

\footnotetext{
${ }^{15}$ Dwi Setio Budiono Santoso, "Peran Khotbah Gembala Sidang Dalam Pertumbuhan Rohani Jemaat," MAGNUM OPUS: Jurnal Teologi dan Kepemimpinan Kristen (2020).

${ }^{16}$ Anderson, Menjadi Gereja Pembuat Murid (Jakarta: Yayasan Gloria, 2016), 33.

${ }^{17}$ Saly and Hutahaean, "PENGARUH KHOTBAH DALAM IBADAH MINGGU TERHADAP KEDEWASAAN IMAN JEMAAT DI GKSI MERAUKE."

${ }^{18}$ Rey, "Khotbah Pengajaran Versus Khotbah Kontemporer."

${ }^{19}$ AMOS WINARTO OEI, "Khotbah Yang Kontekstual : Memuridkan Para Pengkhotbah Untuk Memuridkan Jemaat," SOLA GRATIA: Jurnal Teologi Biblika dan Praktika 5, no. 1 (2020).
} 
Model penyampaian firman meenwnggunakan lebih menekankan akuntabilitas firman Tuhan, berdasarkan penjelasan Firman Tuhan yang diungkapkan dalam tindakan memuji Tuhan. ${ }^{20}$ Pemberitaan firman tidak didasarkan pada pendapat banyak orang, tetapi berpedoman pada kebenaran yang berasal dari Alkitab, yang dipercaya sebagai firman Tuhan tanpa salah yang memiliki otoritas dan wibawa ilahi. Contoh kotbah ini didasarkan pada kesadaran diri dari komunitas pendengar. Setelah mengakui keberadaan Tuhan yang berdaulat, Pencipta langit dan bumi, komunitas pendengar mengakui dirinya dan menginternalisasi informasi otoritatif Alkitab dengan pernyataan khusus dari Tuhan dan nilai-nilai yang berasal dari Alkitab. mengatasi realitas absolut, Tuhan yang paling suci.

Sementara itu, model lain dari pembawaan suatu kotbah adalah model kotbah kontemporer. Kotbah kontemporer dikenal juga dengan kotbah kekinian atau mengikuti perkembangan zamankarena ada sebagaian orang yang menganggap bahwa sistem kotbah yang ada tidak mengikuti perkembangan zaman. ${ }^{21}$ Kotbah modern didasarkan pada aspek informasi karena menganggap masa kini, yang dulu dikenal sebagai era Industri dan sekarang berkembang menjadiera Informasi. Di era informasi ini, kebutuhan kotbah perlu disesuaikan dengan kebutuhan gereja, karena kebutuhan gereja yang satu dengan yang lain berbeda - beda tergantung dari lokasi dan segmen jemaat. Kotbah modern memiliki makna yang dapat diterima melalui transmisi informasi yang dihasilkan dari dekonstruksi bahasa dan teks melaluitanggapan akan kebutuhan kontekstual jemaat setempat.

Model kotbah dapat melibatkan pemikiran irasional, menekankan emosi, intuisi relatif, harmoni, dan kontinuitas. Kotbah modern penuh dengan interpretasi, dan karena kebenarannya relatif, ia juga mempengaruhi perilaku di kedua arah. Kotbah modern menggunakan teks alkitabiah, tetapi interpretasi yang dihasilkan tidak menjelaskan teks, melainkan memperkuat interpretasi relatif berdasarkan kepuasan emosional dan intuitif pengkotbah. Penafsiran yang dinyatakan dari teks Alkitab adalah kebenaran praktis dan emosional. Dengan bantuan teks cerita, jemaat dimasukkan ke dalam situasi emosional. Karena kebenaran hanya diterima sebagian dan tidak muncul dari keheningan mutlak dari Tuhan yang berpribadi, kebenaran itu menjadi kebenaran universal atau mutlak yang menjadi miliknya. Sehingga melalui kebenaran itu pendengar atau jemaat mengalami pertumbuhan iman.

\footnotetext{
${ }^{20}$ Sunarto, "Integritas Seorang Pengkhotbah Dan Kualitas Khotbah Dalam Pemberitaan Firman Tuhan,” TE DEUM (Jurnal Teologi dan Pengembangan Pelayanan) (2021).

${ }^{21}$ Rey, "Khotbah Pengajaran Versus Khotbah Kontemporer." 


\section{Melihat Dari Dekat Kotbah Topikal}

Pengkotbah di dalam menyampaikan kotbah bisa menggunakan berbagai metode. Metode kotbah yang populer digunakan di masa modern ini salah satunya adalah Metode Kotbah Topikal.Metode kotbah topikal menjadi populer dipakai oleh para pendeta dan hamba Tuhan karena dianggap lebih kontekstual dengan situasi serta kondisi yang dialami oleh jemaat setempat.Kotbah topikal merupakan suatu kotbah yang didasarkan pada topik yang telah terlebih dahulu ditentukan. Bagian utama dari kotbah jenis ini diambil dari topik atau tema kotbah itu sendiri. Kotbah topikal termasuk ke dalam model kotbah kontemporer karena membangun sebuah naskah kotbah dengan mencari ayat pada Alkitab yang relevan dengan topik kotbah yang dipilih, Pada umumnya, kotbah topikal mengambil topik yang dekat dengan kehidupan sehari-hari. Itulah sebabnya kotbah jenis ini tidak menggali teks secara langsung sebagai dasar dalam menrekonstruksi bagian utama dari kotbah tersebut.

Kotbah Topikal merupakan bentuk kotbah yang berfokus pada satu topik bahasan dimana terdiri dari point dan sub-point mendukung dari topik bahasan tersebut. Kelebihan kotbah ini adalah lebih mudah dipersiapkan oleh pengkotbah, lebih menarik, dan jemaat dari berbagai kalangan mungkin saja mampu untuk memahami dan mengerti topik yang disampaikan. Jemaat akan mempelajari materi dan ayat-ayat yang mendukung materi tersebut. Kelemahan kotbah ini adalah membuka banyak ayat alkitab tanpa melihat konteks ayat yang dikutip, sehingga akan menimbulkan kebosanan jika tidak pandai berdakwah. Karena hampir setiap kalimat memiliki ayat yang diawali dengan Alkitab. ${ }^{22}$ Seperti kotbahkotbah modern, kotbah-kotbah saat ini adalah emosi massa, baik pengkotbah maupun audiens, dipengaruhi oleh emosi dan opini. Namun, perlu diperhatikan bahwa isi kotbah masih perlu didasarkan pada Alkitab dengan memilih bagian-bagian Alkitab yang sesuai untuk menjelaskan bagian utama dengan benar. ${ }^{23}$ Sayangnya, beberapa pengkotbah tidak memahami sifat kotbah topikal dengan menggunakan bagian dalam Alkitab sebagai penutup untuk topik yang dikotbahkan.

Dalam penyusunan kotbah topikal, pengkotbah akan mengambil sebuah tema dan menentukan poin-poin penting yang dibahas berdasarkan tema tersebut, kemudian mencari ayat Alkitab yang relevan dan menjelaskan topik yang dibahas. ${ }^{24}$ Pengkotbah yang memilih untuk menggunakan kotbah jenis ini harus mengumpulkan bahan dari berbagai bagian

\footnotetext{
${ }^{22}$ Sibarani, "Studi Evaluatif Model Khotbah Topikal Bagi Pengkhotbah Kristen."

${ }^{23}$ Mortan Sibarani, "DESKRIPSI TENTANG KHOTBAH YANG BERKUASA SECARA ALKITABIAH,” Phronesis: Jurnal Teologi dan Misi (2020).

${ }^{24}$ Sibarani, "Studi Evaluatif Model Khotbah Topikal Bagi Pengkhotbah Kristen." 
Alkitab yang berbicara tentang suatu pokok dan dari bahan itulah dirangkai menjadi sebuah kotbah yang utuh dan komperhensif. Karena itu, jenis kotbah ini akan lebih efektif digunakan oleh pengkotbah yang memiliki dasar teologi yang cukup dan menguasai isi Alkitab secara keseluruhan. Kotbah topikal biasanya akan lebih mudah menarik pendengar karena topik yang disusun disesuaikan dengan kebutuhan jemaat dan berusaha se-relevan mungkin dengan kehidupan jemaat sehari-hari. ${ }^{25}$ Kotbah jenis ini juga lebih mudah dicerna, diterima, dan dipahami oleh pendengar karena inti kotbah cenderung terarah pada satu topik bahasan saja. Cara ini membuat kotbah menjadi lebih praktis, jelas, dan teratur karena mampu menimbulkan kesan yang mendalam kepada para jemaat. Yang paling penting dari kotbah topikal ini adalah dapat memperluas pengetahuan pengkotbah maupun jemaat untuk memperdalam sebuah topik menurut pandangan yang Alkitabiah.

Kotbah topikal harus dipraktikkan oleh pengkotbah yang memahami betul isi Alkitab secara holistik. Jika tidak, hal ini akan menimbulkan kekeliruan dalam berbagai aspek. Pemahaman yang kurang mendalam akan menyebabkan pengkotbah sering mengabaikan konteks dari Alkitab itu sendiri, karena kita sering menggunakan puisi asli yang berbicara atau berhubungan dengan subjek. ${ }^{26}$ Pemilihan ayat yang terlalu banyak (sesuai poin-poin tema kotbah) hanya akan membuat jemaat jenuh dan terganggu dalam menyampaikan idenya. Kotbah topikal dapat menjebak pengkotbah memakai pikiran dan pengetahuan manusianya saja, tanpa melihat jawaban Alkitab yang sesungguhnya; sehingga mengorbankan kebenaran Alkitab. Yang paling mengkhawatirkan dalam kekeliruan pemaknaan kotbah topikal adalah pengkotbah dapat memperalat Alkitab untuk mencapai tujuan pribadinya sehingga tujuan firman yang murni menjadi diabaikan. Dalam menyampaikan kotbah dengan metode ini,cara penyampaian atau pengkomunikasikan isi kotbah sangat berpengaruh terhadap penerimaan oleh jemaat.

Kegagalan seorang pengkotbah dalam membangun komunikasi kepada jemaat melalui firman berakibat fatal baik secara pribadi maupun secara koorporat. ${ }^{27} \mathrm{Hal}$ ini mengindikasikan bahwa kotbah dengan metode apapun berusaha menyampaikan kerangka komunikasi yang bertanggung jawab dan adanya perubahan orientasi yang lebih baik meliputi unsur praktis dan teologis. Dengan merekonstruksi kerangka penyampaian kotbah yang berdasarkan injil melalui pemahaman dari Roh Kudus, diharapkan mampu mengubah

\footnotetext{
${ }^{25}$ Ibid.

${ }^{26}$ Marsi Bombongan Rantesalu, "Pengaruh Khotbah Bagi Pertumbuhan Gereja,” Integritas: Jurnal Teologi (2021).

${ }^{27}$ Dani. Vardiansyah, Filsafat Llmu Komunikasi: Suatu Pengantar (Jakarta: Indeks, 2008), 2. 
cara berfikir dan bertindak jemaat dalam berpikir dan berperilaku di tengah masyarakat luas sehingga memberi dampak yang dapat dipertanggungjawabkan secara teologis dan praksis. Untuk menghindari kekeliruan yang mungkin terjadi dalam menerapkan kotbah topikal, sangat penting untuk memperhatikan kemampuan pengetahuan dan pemahaman pengkotbah terhadap Alkitab secara keseluruhan.

\section{Perspektif Gereja Aliran Pentakosta Terkait Kotbah Topikal}

Pentakostalisme atau aliran pentakostal merupakan suatu paham atau aliran gereja yang menganggap karunia-karunia roh sebagai ciri terpenting orang Kristen serta menekankan kebangunan rohani, baptisan Roh Kudus, bahasa roh, doa penyembuhan, dan tentang kerajaan seribu tahun ${ }^{28}$. Adapun gerakan Pentakosta itu sendiri dimulai saat peristiwa pencurahan Roh Kudus yang terjadi di loteng Yerusalem yang ditandai dengan bahasa lidah (xenolalia) diikuti oleh karunia-karunia lain yang ditunjukkan oleh para rasul melalui doa penyembuhan, kecuali hantu, penglihatan, nubuat dan mukjizat lainnya. ${ }^{29}$ Kuasa yang dialami oleh setiap orang pada saat itu datangnya dari Roh Kudus yang dimaksudkan untuk melengkapi orang percaya untuk melaksanakan pesan agung Tuhan Yesus sebagai saksi-Nya ke seluruh dunia (Kisah 1: 8). Orientasi teologi yang didominasi oleh isu-isu pneumatologiatau manifestasi karya Roh kudus telah menjadi karakteristik gereja-gereja Pentakosta hingga modern ini. ${ }^{30}$

Pada umumnya para ahli Pentakosta menyebutkan teologi gereja aliran Pentakosta didominasi oleh terkait ajaran Pentakosta yang terdiri dari empat pilar, yaitu: Keselamatan, Kesembuhan, Baptisan Roh Kudus, dan Kedatangan Kristus. Gereja Pantekosta tidak merasakan bahwa mereka telah menciptakan doktrin atau standar baru. Dengan memberitakan “ Full Gospel/ Injil Sepenuh “, mereka merasa bahwa benar-benar menekankan kembali ajaran asli Alkitab yang sudah ada, tanpa menanggalkan ortodoksi hanya lebih berfokus kepada pnumatologi atau karunia roh Kudus. Sehingga beberapa ahli berpendapat gereja Aliran pentakosta memiliki teologi “Dunamis” atau Teologi yang digerakan oleh kuasa Roh Kudus. ${ }^{31}$ Dimana Kualitas pengajaran inilah yang pada akhirnya membuat stigma Pentakosta menjadi stigma eksklusivisme. Lebih mengacu kepada

\footnotetext{
${ }^{28}$ Kamus Teologi, Henk Ten Napel (Jakarta: BPK Gunung Mulia, 2000), 242.

${ }^{29}$ Steven H. Talumewo, Sejarah Gerakan Pentakosta (Yogyakarta: Andi Offset, 2008).

${ }^{30}$ Bobby Kurnia Putrawan, "Pengantar Teologi Pentakosta (Introduction To Pentecostal Theology)," QUAERENS: Journal of Theology and Christianity Studies (2019).

${ }^{31}$ Walter J. Hollenweger, Pentecostalism Origins and Developments World Wide. 
masalah-masalah spiritual (hubungan vertikal) daripada sosial, budaya, atau bahkan politik (hubungan horizontal). ${ }^{32}$ Mereka menjalani kehidupan yang positif dan saleh, berpartisipasi dalam kebaktian gereja, dan tidak memiliki kepekaan sosial yang seimbang. Kisah Para Rasul 2:42 mengacu pada karakter dari Pentakosta awal ini. Mereka berpegang teguh pada ajaran dan komunitas para rasul. Pentakosta awal adalah orang-orang baik yang terobsesi dengan persekutuan yang dimotori oleh kuasa Roh Kudus. ${ }^{33}$ Dalam konteks ini, dapat diterjemahkan bahwa orang Pentakosta tidak akan kehabisan cara dan materi untuk menyampaikan kotbah atau pewartaan kepada orang-orang yangbelum mendengarkan firman Tuhan. Beberapa ayat dalam Alkitab menuntun orang percaya untuk mengalamipengenalan akan Allah, yang kemudian menghasilkan standar hidup yang harus mampu dipertanggungjawabkan.

Pekerjaan para rasul pada kekristenan awal adalah pekerjaan yang menekankan kuasa Tuhan. Para rasul diangkat secara luar biasa oleh Allah dengan otoritas yang luar biasa dari Tuhan Yesus. Hal serupa biasa terjadi selama periode ini dan sekarang menjadi salah satu ciri Pentakosta atau karismatik. Mereka menunjukkan kuasa dengan "melayani” atau dengan memberitakan Injil, dan seperti apa yang sah menurut janji-janji Firman Tuhan. Di antara banyak karakter yang Tuhan jalani dengan cara yang tidak biasa, banyak yang berakhir dalam dosa. Ini bukan preseden, tetapi Tuhan cenderung meningkatkan pengalaman spiritual seseorang, dan dia runtuh ketika angin pencobaan meningkat.

Melalui pemahaman tentang kotbah topikal dan Pentakosta, kita mengetahui bahwa menurut perspektif Pentakosta yang didasari oleh Alkitab, tidak ada larangan khusus dalam berkotbah selagi kotbah tersebut didasari oleh pengetahuan dan pemahaman mendalam tentang Alkitab dan Alkitab tetap menjadi pegangan utama dalam melakukan kotbah. Kotbah dapat dilakukan dengan cara apapun termasuk dengan metode kotbah topikal. Namun kotbah topikal harus tetap memperhatikan aspek-aspek penting dalam kekristenan dan pemahaman yang holistik terhadap isi Alkitab. Pengkotbah perlu mewaspadai penyalahgunaan metode topikal yang memasukkan gagasan ke dalam teks Alkitabiah (eisegesis)

Hal yang harus dipahami baik oleh pengkotbah maupun jemaat adalah Kotbah tidak memuat penjelasan kosong berdasarkan sistem berpikir manusia. Sebaliknya, berkotbah

\footnotetext{
${ }^{32}$ William Horton, Doktrin Alkitab: Menurut Pandangan Pentakosta (Malang: Gandum mas, 2003), 49.

${ }^{33}$ Daniel Sutoyo, “Allah Memanggil Umat-Nya Untuk Menjadi Gereja Yang Tekun Berdoa Menurut Kisah Para Rasul 4: 23 - 31," DUNAMIS: Jurnal Penelitian Teologi dan Pendidikan Kristiani 1, no. 1 (2016): 52.
}

Copyright@2021; Ritornera - Jurnal Teologi Pentakosta Indonesia, ISSN 2797-7676 (online), 2797$717 x$ (print) $\mid 36$ 
harus setia secara umum, dan khususnya untuk memberitakan kebenaran Allah. Namun demikian, hasil interpretasi yang disampaikan melalui kotbah harus dapat diandalkan, layak, atau dapat dihitung dan dapat diterapkan. Tujuan kotbah sangat erat kaitannya dengan khatib dan persepsi yang telah dibangun melalui pokok-pokok kotbah. Dari segi epistemologis, pengetahuan, termasuk batasan, landasan, validitas, validitas, apresiasi, kritik, norma, dan objek pengetahuan, adalah pemberitaan alkitabiah dan menyampaikan seluruh realitas yang berhubungan dengan Tuhan.

Berangkat dari sudut pandang teori nilai (esensi nilai, termasuk etika, estetika, dan spiritualitas), kotbah menjelaskan hakikat nilai-nilai penting yang terkandung dalam premis kebenaran Alkitab yang berkaitan dengan Tuhan dengan menghadirkan realitas universal yang dimiliki seseorang. ${ }^{34}$ Kotbah merupakan kombinasi antara isi Alkitab dan pemahaman pokokiman sehingga memberikan pengajaran nilai kehidupan luhur kepada jemaat. Nilai kehidupan yang diturunkan didasarkan pada makna ontologis dan epistemologis yang jelas dari kebenaran Allah. Tanpa pemahaman yang benar secara ontologi dan epistemologi, praktik kehidupan pribadi tidak akan pernah mengarah pada nilai-nilai empiris yang jelas.

Pada gereja - gereja aliran Pentakosta Pengkotbah yang menggunakan metode topikal harus memahami betul isi Alkitab secara holistikserta dasar teologia yang cukup. Kurangnya pemahaman yang mendalam menyebabkan pengkotbah sering menggunakan ayat acak untuk berbicara dan berhubungan dengan jemaat yang justru sering mengabaikan konteks Alkitab itu sendiri. Pengkotbah cenderung memilih terlalu banyak ayat (sesuai dengan pokok-pokok topik kotbah) hanya akan membuat jemaat bosan. Para pengkotbah gereja Pentakosta percaya bahwa Roh Kudus akan menuntun pengkotbah untuk dapat mempersiapkan dan menyampaikan kotbah sehingga tepat pada sasaran.Mereka percaya Roh Kudus yang Maha Tau mengetahui pergumulan jemaat dan mengilhamkan topik dan ayat yang sesuai untuk dikotbahkan.

Dalam menyampaikan kotbah topikal, cara penyampaian pengkotbah atau pengkomunikasikan isi kotbah sangat berpengaruh terhadap penerimaan jemaat. Karena pada hakekatnya orang pentakosta percaya Roh kudus yang menghidupkan firman dalam diri jemaat sehingga dapat teraplikasi dalam perbuatan nyata di tengah masyarakat. Hal ini berimplikasi pada pemahaman bahwa kotbah yang disampaikan oleh pengkotbah kiranya menekankan pada ajaran tentang apa yang ingin disampaikan oleh Allah kepada manusia. Roh Kudus sangat berperan dan menjadi pusat dalam kerohanian orang percaya dalam

\footnotetext{
${ }^{34}$ Scharf, Khotbah Yang Transformatif (Jakarta: Yayasan Komunikasi Bina kasih, 2013), 8.
} 
melakukan kebenaran. ${ }^{35}$ Menjadi kekawatiranpada kotbah di gereja Pentakosta dewasa ini adalah para pengkotbah dapat menggunakan Alkitab untuk mencapai tujuan pribadi mereka dan tujuan utama dari firman itu cenderung diabaikan. Untuk itulah kotbah harus mendekati realita hidup pendengar. ${ }^{36}$ Kotbah harus dihubungkan dengan kehidupan gereja saat ini. Pengkotbah harus mampu menunjukkan peran dan hak-hak Tuhan dalam kehidupan setiap jemaat. Tujuan akhirnya supaya pendengar mampu melihat dan mempercayakan hidupnya kepada Tuhan serta mengandalkan kuasa Roh Kudus. ${ }^{37}$

\section{KESIMPULAN}

Aliran pentakosta merupakan sebuah perjalanan kekristenan yang mengalami dinamisasi karena peran Roh kudus dalam gerejaNya, sehingga sepanjang zaman Roh kudus menghidupkan setiap potensi ilahi yang dimiliki oleh setiap umat secara maksimal dalam rangka memiliki kehidupan yang berdampak bagi banyak orang guna mewartakan amanat agung Tuhan Yesus. Untuk mendidik umat yang kuat dan militan diperlukan doktrinasi melalui bentuk - bentuk kotbah yang telah berjalan sepanjang umur gereja. Salah satu yang dikenal selama ini adalah kotbah topikal, bagi kalangan Pentakosta memaknainya kotbah ini sebagai salah satu cara penyampaian isi Alkitab yang relevan dan dekat dengan kehidupan jemaat sehari-hari dengan tetap memperhatikan aspek pengetahuan yang mendalam tentang Alkitab itu sendiri, sebab Tuhan sendiri tidak membatasi cara manusia dalam berkotbah atau menyampaikan firman Tuhan.

Orang Pentakosta percaya bahwa Roh Kudus akan menuntun pengkotbah untuk dapat mempersiapkan dan menyampaikan kotbah sehingga tepat pada sasaran. Dalam perspektif aliran Pentakosta, kotbah topikal merupakan salah satu metode kotbah yang mudah dimengerti, tidak ada yang salah dengan metode ini hanya saja yang penting untuk diperhatikan adalah landasan

\footnotetext{
${ }^{35}$ Yonatan Alex Arifianto and Asih sumiwi Rachmani, "Peran Roh Kudus Dalam Menuntun Orang Percaya Kepada Seluruh Kebenaran Berdasarkan Yohanes 16 : 13,” Jurnal Diegesis (2020).

${ }^{36}$ Kleden, Allah Menggugat Allah Menyembuhkan (Maumere: Ledalero, 2014), 234.

${ }^{37}$ Kleden, Allah Menggugat Allah Menyembuhkan.
} 
Alkitabiah dari kotbah yang disampaikan tidak boleh melenceng dari isi atau pemaknaan Alkitab itu sendiri. Oleh sebab itu penting bagi seorang pengkotbah untuk selalu mengandalkan kuasa Roh Kudus dalam setiap kotbah - kotbahnya. Sehingga kuasa dan mujizat Allah menyertai dan meneguhkan setiap kotbah kotbah yang disampaikan.

\section{REFERENSI}

Anderson. Menjadi Gereja Pembuat Murid. Jakarta: Yayasan Gloria, 2016. Andreas B. Subagyo. PENGARUH KHOTBAH DALAM IBADAH MINGGU TERHADAP KEDEWASAAN IMAN. Bandung: Kalam Hidup, 2000.

Arifianto, Yonatan Alex, and Asih sumiwi Rachmani. "Peran Roh Kudus Dalam Menuntun Orang Percaya Kepada Seluruh Kebenaran Berdasarkan Yohanes 16: 13.” Jurnal Diegesis (2020).

Evans, William. Cara Mempersiapkan Khotbah. Jakarta: BPK Gunung Mulia, 2011.

Hasan Sutanto. Homiletik, Prinsip Dan Metode Berkhotbah. Jakarta: BPK Gunung Mulia, 2014.

Horton, William. Doktrin Alkitab: Menurut Pandangan Pentakosta. Malang: Gandum mas, 2003.

Jan S. Aritonang. Berbagai Aliran Di Dalam Dan Di Sekitar Gereja. Jakarta: Gunung Mulia, 2016.

John Dami Mukese. Homiletika: Seni Berkhotbah Efektif. Yogyakarta: Nusa Indah, 2010.

Kamus Teologi. Henk Ten Napel. Jakarta: BPK Gunung Mulia, 2000.

Kleden. Allah Menggugat Allah Menyembuhkan. Maumere: Ledalero, 2014.

Mark J. Cartledge. The Cambridge Companion to Pentacostalism. USA: Cambridge University Press, 2014.

OEI, AMOS WINARTO. "Khotbah Yang Kontekstual: Memuridkan Para Pengkhotbah Untuk Memuridkan Jemaat." SOLA GRATIA: Jurnal Teologi Biblika dan Praktika 5, no. 1 (2020).

Putrawan, Bobby Kurnia. "Pengantar Teologi Pentakosta (Introduction To Pentecostal Theology)." QUAERENS: Journal of Theology and Christianity Studies (2019).

Rantesalu, Marsi Bombongan. "Pengaruh Khotbah Bagi Pertumbuhan Gereja." Integritas: Jurnal Teologi (2021).

Rey, Kevin Tonny. "Khotbah Pengajaran Versus Khotbah Kontemporer." DUNAMIS: Jurnal Penelitian Teologi dan Pendidikan Kristiani (2016).

Saly, Jansakti Saddu, and Hasahatan Hutahaean. "PENGARUH KHOTBAH DALAM IBADAH MINGGU TERHADAP KEDEWASAAN IMAN JEMAAT DI GKSI MERAUKE.” VISIO DEI: JURNAL TEOLOGI KRISTEN (2020).

Santoso, Dwi Setio Budiono. "Peran Khotbah Gembala Sidang Dalam Pertumbuhan Rohani Jemaat." MAGNUM OPUS: Jurnal Teologi dan Kepemimpinan Kristen (2020).

Scharf. Khotbah Yang Transformatif. Jakarta: Yayasan Komunikasi Bina kasih, 2013.

Sibarani, Mortan. "DESKRIPSI TENTANG KHOTBAH YANG BERKUASA SECARA ALKITABIAH.” Phronesis: Jurnal Teologi dan Misi (2020).

Sibarani, Yosua. "Studi Evaluatif Model Khotbah Topikal Bagi Pengkhotbah Kristen." Jurnal Teologi (JUTEOLOG) (2020).

Steven H. Talumewo. Sejarah Gerakan Pentakosta. Yogyakarta: Andi Offset, 2008. 
Sudarmin Purwocaroko. Homiletika Theologia Praksis Sajian Khotbah Alternatif. Yogyakarta: Narmada, 2010.

Sunarto. "Integritas Seorang Pengkhotbah Dan Kualitas Khotbah Dalam Pemberitaan Firman Tuhan.” TE DEUM (Jurnal Teologi dan Pengembangan Pelayanan) (2021).

Sutoyo, Daniel. “Allah Memanggil Umat-Nya Untuk Menjadi Gereja Yang Tekun Berdoa Menurut Kisah Para Rasul 4: 23 - 31.” DUNAMIS: Jurnal Penelitian Teologi dan Pendidikan Kristiani 1, no. 1 (2016): 52.

Tiara Asrilita. "Studi Homiletika Pengaruh Pengkhotbah Tamu Dalam Pertumbuhan Iman Di JKI Immanuel Kudus.” SKRIPSI: Universitas Kristen Satya Wacana (2019).

Vardiansyah, Dani. Filsafat Llmu Komunikasi: Suatu Pengantar. Jakarta: Indeks, 2008.

Walter J. Hollenweger. Pentecostalism Origins and Developments World Wide. USA: Hendrickson Publisher, 1997.

Zaluchu, Sonny Eli. "Strategi Penelitian Kualitatif Dan Kuantitatif Di Dalam Penelitian Agama." Evangelikal: Jurnal Teologi Injili dan Pembinaan Warga Jemaat 4, no. 1 (2020): 28. 